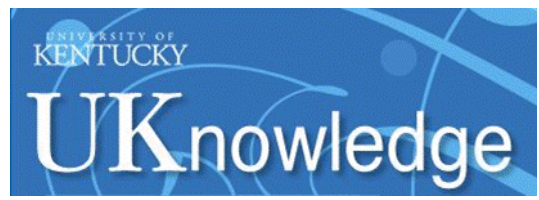

University of Kentucky

UKnowledge

Biosystems and Agricultural Engineering Faculty Publications

7-9-2013

\title{
The Use of Co-Culturing in Solid Substrate Cultivation and Possible Solutions to Scientific Challenges
}

\author{
Wanying Yao \\ University of Kentucky \\ Sue E. Nokes \\ University of Kentucky, sue.nokes@uky.edu
}

Follow this and additional works at: https://uknowledge.uky.edu/bae_facpub

Part of the Bioresource and Agricultural Engineering Commons, and the Biotechnology Commons Right click to open a feedback form in a new tab to let us know how this document benefits you.

\section{Repository Citation}

Yao, Wanying and Nokes, Sue E., "The Use of Co-Culturing in Solid Substrate Cultivation and Possible Solutions to Scientific Challenges" (2013). Biosystems and Agricultural Engineering Faculty Publications. 169.

https://uknowledge.uky.edu/bae_facpub/169

This Article is brought to you for free and open access by the Biosystems and Agricultural Engineering at UKnowledge. It has been accepted for inclusion in Biosystems and Agricultural Engineering Faculty Publications by an authorized administrator of UKnowledge. For more information, please contact UKnowledge@lsv.uky.edu. 


\section{The Use of Co-Culturing in Solid Substrate Cultivation and Possible Solutions to Scientific Challenges}

\section{Digital Object Identifier (DOI)}

https://doi.org/10.1002/bbb.1389

\section{Notes/Citation Information}

Published in Biofuels, Bioproducts and Biorefining, v. 7, issue 4, p. 361-372.

Copyright @ 2013 Society of Chemical Industry and John Wiley \& Sons, Ltd

This is the peer reviewed version of the following article: Yao, W., \& Nokes, S. E. (2013). The use of coculturing in solid substrate cultivation and possible solutions to scientific challenges. Biofuels, Bioproducts and Biorefining, 7(4), 361-372. doi: 10.1002/bbb.1389, which has been published in final form at https://doi.org/10.1002/bbb.1389. This article may be used for non-commercial purposes in accordance with Wiley Terms and Conditions for Use of Self-Archived Versions. 


\title{
Perspective: The Use of Co-culturing in Solid Substrate Cultivation and Possible Solutions to Scientific Challenges
}

\author{
Wanying Yao ${ }^{a}$, *Sue E. Nokes ${ }^{a}$ \\ ${ }^{a}$ Department of Biosystem and Agicultural Engineering, University of Kentucky \\ 128 C.E. Barnhart Building \\ Lexington, KY, US \\ E-mail: Julia.yao@uky.edu; snokes@uky.edu
}

\begin{abstract}
This perspective systematically summarizes the use of solid substrate co-cultures in agriculture, food, plant and industrial biotechnology applications. The summarization is organized by organism, i.e. fungus, bacteria, yeast and then co-cultivation of either two or three organisms. Generally, in solid substrate co-culture, the organisms synergistically penetrate and degrade the solid substrate thereby increasing product yield and productivity over a monoculture. Efforts to increase co-culture performance include optimizing process parameters $(\mathrm{pH}$, temperature, moisture and oxygen demand) and defining the acceptable types of substrate. Scientific challenges exist in understanding the interactions between microbial stains, such as viability, suite of products, and bio-transformations. The perspective details possible solutions to these challenges and highlights future research directions for co-cultures using either solid or liquid fermentation.
\end{abstract}

Key words: solid substrate cultivation, co-cultural microorganisms, lignocellulosic biomass, bioproducts and biofuels

\section{Background}

Currently, industrial demand for bioproducts is predominately being met using submerged fermentation $(\mathrm{SmF})$ processes, generally employing modified strains of microorganisms. 
However the cost of production in SmF systems is prohibitive for many commodity chemicals. Production cost can be reduced by deploying alternative methods such as solid substrate cultivation (SSC) systems. ${ }^{1-3}$

Microbial consortia consisting of two or more microorganisms are responsible for many biotransformations in natural environments. ${ }^{4}$ Interactions between the organisms can be triggered either through direct cell-to-cell communications or by signal substances that can bind to cellsurface proteins in the fermentation broth. ${ }^{5}$ In other words a stable co-culture could be maintained by the interactions of syntrophic relationships, competition for substrates as well as growth promoters or inhibitors such as antibiotics. ${ }^{5,6}$ For example, one of the syntrophic interactions in co-cultures is the widely distributed phenomenon of interspecies hydrogen transfer between sulfate reducers such as Syntrophobacter sp. and methanogens, where carbon dioxide is reduced into methane by obtaining the energy from hydrogen. ${ }^{7,8}$

Currently, co-culture SmF fermentations (mostly positive interactions) are widely used in the production of antibiotics, enzymes, fermented food, composting and bioconversion of wastewater sludge. ${ }^{9}$ Although not as widely applied as co-cultures in SmF, the advantages of cocultures may be even more pronounced in SSC, because the colonization, penetration, and degradation of the solid substrate depends on a symbiotic association where each species can synergistically function with the other specie(s) in a substrate niche via a specific set of enzymes. 10

\section{Fungal co-culture under SSC}

Filamentous fungi typically grow in symbiotic associations on solid substrates, such as wood, seeds, stems, roots and leaves of plants. ${ }^{11}$ Similar to natural microbial processes, cultivation of mixed species of fungi can demonstrate more effective utilization of the substrate, increased productivity of the desired metabolites owing to comprehensive enzyme mixtures and higher

resistance to contamination. ${ }^{10,12}$ In addition, fungal solid substrate cultivation is a low-cost fermentation process particularly suited to the needs in developing pilot scale processes, or producing high volume, low cost commodity chemicals. ${ }^{13}$

\subsection{Production of lignocellulolytic enzymes and enzymes mixtures}


The composition of lignocellulosic waste/biomass is complex and therefore requires multiple enzymes for decomposition. ${ }^{10}$ Ligninolytic, cellulolytic, pectinolytic and xylanolytic enzymes are the main hydrolytic enzyme systems that either pretreat biomass or generate reducing sugars. Ligninolytic enzymes (lignin peroxidase, manganese peroxidase and laccase), directly and specifically attack lignin and oxidize it, often rendering the lignin water soluble, which enable the utilization of this complex biopolymer for the production of fine chemicals. ${ }^{14}$ A cellulolytic enzyme system hydrolyzes lignocellulosic biomass synergistically using endoglucanase, exoglucanase and $\beta$-glucosidase. ${ }^{15}$ Xylanase complements the cellulolytic enzyme system as xylanase is needed to elicit complete and efficient hydrolysis of the lignocellulosic biomass, which contains an appreciable amount of hemicellulose in both hardwood and herbaceous biomass - composed of xylan predominately. ${ }^{16}$

The association of two or more fungi results in higher enzyme production, which by acting synergistically, effectively degrades various biomass or agricultural wastes. Among the cellulolytic fungi, genera like Trichoderma, Aspergillus, Penicillium and Fusarium are regarded as cellulase producers. ${ }^{17}$ The feasibility and performance of mixed cultures (either of different species or genera) using industrial and agricultural carbon wastes were investigated and enhanced by optimizing incubation time, carbon sources and initial $\mathrm{pH}$ of the fermentation medium ${ }^{18-21}$ and are specified below.

Aspergillus is by far the most efficient producer of $\beta$-glucosidase among the microorganisms investigated in terms of high, active and stable enzymatic properties maintained at the existence of inhibitors and broad $\mathrm{pH}$ range. ${ }^{9,} 22$

Strains of Trichoderma can accumulate high activities of endo and exo-glucanase, but are deficient in $\beta$-glucosidase whereas some strains of Aspergillus have high $\beta$-glucosidase activity. ${ }^{23-25}$ Therefore, strains of both Trichoderma and Aspergillus can be successfully cultivated together in SSC to produce multi-complex cellulase systems as reported in Table 1 (see Supplement for detailed discussion of studies). ${ }^{16,19,20,26,27}$ Besides the improvement in the activity of individual enzyme system, co-culturing two or more fungal strains using SSC can also produce multiple enzyme complexes. ${ }^{10,28-30}$ 
As evidenced in Table 1, fungal co-cultures regulated the complete utilization of the complex biomass by producing a variety of different enzymes complexes. Even for the same species, different strain combinations can correspond to different enzyme complexes. The informed selection of compatible microorganisms in mixed fungal systems can correspond to the desired enzymatic levels and compositions in order to accomplish different objectives. For a selection of an optimum fungal system as related to strain compatibility, a direct target is the high yield of enzyme activities. Besides the activity of enzyme, enzyme volumetric productivities (the amount of enzyme produced per $\mathrm{m}^{3}$ bioreactor volume per unit time) can be used as a criteria to evaluate the performance of co-cultures as compared to mono culture. 
Table 1 List of fungal co-cultures for hydrolytic enzymes

\begin{tabular}{|c|c|c|c|c|}
\hline Product & Substrate & $\begin{array}{l}\text { Increased amount as } \\
\text { comparisons to monoculture }\end{array}$ & Co-culturing strains & References \\
\hline $\begin{array}{l}\text { Xylanase and } \\
\text { laccase }\end{array}$ & $\begin{array}{l}\text { Mixed wood } \\
\text { pulp }\end{array}$ & Not specified & $\begin{array}{l}\text { Mutant Penicillium oxalicum } \\
\text { SAUE-3.510 and Pleurotus } \\
\text { ostreatus MTCC } 1804 \text { (ratio not } \\
\text { specified) }\end{array}$ & 26 \\
\hline $\begin{array}{l}\text { Mixture of } \\
\text { Laccase, and } \\
\text { glucoamylase or } \\
\beta \text {-glucosidase }\end{array}$ & Wheat bran & $\begin{array}{l}\text { 1.5-fold increase in } \beta \text {-glucosidase } \\
\text { over that of } T \text {. aurantiacus; } 2.5 \text {-fold } \\
\text { increase in laccase over that of } A \text {. } \\
\text { niger, } A ; 1.68 \text {-fold increase in } \\
\text { glucoamylase over that of } T \text {. } \\
\text { aurantiacus }\end{array}$ & $\begin{array}{l}\text { T. aurantiacus with } A \text {. niger } A \text { or } B \\
\text { (ratio not specified) }\end{array}$ & 27 \\
\hline $\begin{array}{l}\text { Laccase and } \\
\text { pectinase }\end{array}$ & $\begin{array}{l}\text { Wheat bran, } \\
\text { oats straw and } \\
\text { beetroot press }\end{array}$ & $\begin{array}{l}\text { 8.4-fold increase in laccase over the } \\
\text { mono culture }\end{array}$ & $\begin{array}{l}\text { A. niger and Fusarium } \\
\text { moniliforme ; Trametes versicolor } \\
\text { and A. niger }\end{array}$ & 10 \\
\hline $\begin{array}{l}\text { Xylanase and } \\
\text { cellulase }\end{array}$ & $\begin{array}{l}\text { Sugarcane } \\
\text { bagasse }\end{array}$ & $\begin{array}{l}35-45 \% \text { increase in xylanase and } \\
20-142 \% \text { increase in cellulase } \\
\text { compared to single cultures of either } \\
\text { partner }\end{array}$ & $\begin{array}{l}\text { T. reesei with either } A \text {. niger or } A \text {. } \\
\text { phoenicis (ratio } 3: 2 \text { ) }\end{array}$ & 28 \\
\hline $\begin{array}{l}\text { Cellulase } \\
\text { complex }\end{array}$ & Waste paper & $\begin{array}{l}\text { Up to } 2.4 \text {-fold increase in cellulase } \\
\text { over mono culture of } A \text {. niger; } 3.7 \text { - } \\
\text { fold increase in cellulase over } T \text {. } \\
\text { viride }\end{array}$ & A. niger and $T$. viride (ratio $1: 1$ ) & 29 \\
\hline$\beta$-glucosidase & $\begin{array}{l}\text { Defined } \\
\text { medium }\end{array}$ & $\begin{array}{l}\text { More than } 10 \text {-fold rise than that of } \\
\text { A. niger or } A \text {. oryzae }\end{array}$ & A. niger and A. oryzae (ratio 3:1) & 9 \\
\hline
\end{tabular}




\begin{tabular}{|l|l|l|l|c|}
\hline $\begin{array}{l}\text { cellulase ( } \beta- \\
\text { glucosidase and } \\
\text { endocellulase) } \\
\text { xylanase }\end{array}$ & $\begin{array}{l}\text { Soybean hulls } \\
\text { supplemented } \\
\text { with wheat bran }\end{array}$ & $\begin{array}{l}\text { 65\% increase in } \beta \text {-glucosidase and } \\
67.3 \% \text { increase in endocellulase } \\
(100 \mathrm{IU} / \mathrm{g} \text { ) compared to that of } T . \\
\text { reesei } 60 \mathrm{IU} / \mathrm{g})\end{array}$ & T. reesei and A. oryzae (ratio 1:1) & 16 \\
\hline $\begin{array}{l}\text { Cellulase, } \\
\text { hemicellulase, } \\
\text { glucoamylase, } \\
\text { pectinase, and } \\
\text { acidic proteinase }\end{array}$ & Bran mash & $\begin{array}{l}\text { At least } 65 \% \text { activity increase for all } \\
\text { the tested enzymes compared to } \\
\text { each mono culture. }\end{array}$ & Species of A. niger (ratio 1:4) & 30 \\
\hline $\begin{array}{l}\text { Cellulase } \\
\text { complex }\end{array}$ & $\begin{array}{l}\text { Sugar cane } \\
\text { bagasse }\end{array}$ & $\begin{array}{l}\text { 1.4-fold increase in } \beta \text {-glucosidase } \\
\text { and 2.9-fold increase in } \\
\text { endoglucanase compared to that of } \\
\text { T. reesei LM-UC4 }\end{array}$ & $\begin{array}{l}\text { T. reesei LM-UC4 and A. phoenicu } \\
\text { (ratio 1:1) }\end{array}$ & 19 \\
\hline $\begin{array}{l}\text { Cellulase } \\
\text { complex }\end{array}$ & Bagasse & $\begin{array}{l}\text { 4.3-fold increase in } \beta \text {-glucosidase; } \\
7.3-\text { fold increase in endoglucanase } \\
\text { over single culture of } \text { T. reesei in } \\
\text { flask culture }\end{array}$ & $\begin{array}{l}\text { T. reesei LM-UC4 and A. phoenicis } \\
\text { QM329 (ratio 2:1) }\end{array}$ & 20 \\
\hline $\begin{array}{l}\text { Cellulase and } \\
\text { hemicellulase }\end{array}$ & Tomato pomace & $\begin{array}{l}\text { Up to } 1.8 \text {-fold increase in cellulose } \\
\text { conversion over mono culture of } T . \\
\text { reesei }\end{array}$ & Trichoderma and Sporotrichum sp & 21 \\
\hline
\end{tabular}




\subsection{Production of tannase and gallic acid}

Tannin acyl hydrolase, commonly called tannase, has been widely used in the food and pharmaceutical industries. Due to its hydrolysis of gallotannin to gallic acid, this enzyme is mainly commercially applied to the synthesis of an antifolate and antibacterial drug trimethoprim..$^{31}$

The following microorganisms; Fungi-Aspergillus sp., Penicillium sp., Rhizopus sp., YeastCandida sp. and bacteria - Bacillus sp. have been used as inoculum for tannase and gallic acid production from tannin-rich substrates using SSC. ${ }^{32,33}$ Various fungal combinations have been investigated successfully, as summarized in Table 2 (see Supplement for detailed discussion of studies). 
Table 2 List of fungal co-cultures for tannase and gallic acid production

\begin{tabular}{|l|l|l|l|l|}
\hline Product & Substrate & Increased amount over mono-culture & Selected co-culturing strains & References \\
\hline $\begin{array}{l}\text { Tannase and } \\
\text { gallic acid }\end{array}$ & Grape waste & $\begin{array}{l}33.3 \% \text { to } 37.7 \% \text { increase in enzyme } \\
\text { volumetric productivity (U/g/min) over } \\
\text { single cultures of either partner }\end{array}$ & $\begin{array}{l}\text { P. chrysogenum and T. viride } \\
\text { (ratio 1:1) }\end{array}$ \\
\hline Tannase & Tamarind seed powder & $\begin{array}{l}35.1 \% \text { to } 57.4 \% \text { increase in enzyme } \\
\text { volumetric productivity (U/g/day) over } \\
\text { single cultures of either partner }\end{array}$ & $\begin{array}{l}\text { R. oryzae (MTCC 1987) and } \\
\text { A. foetidus (MTCC 3557) }\end{array}$ \\
\hline Tannase $1: 1$ )
\end{tabular}




\subsection{Other bioproducts produced from fungal co-cultures}

Fungal co-cultures can produce unique enzymatic complex synergistically transforming raw materials or agricultural residues into high protein biomass or secondary metabolites ${ }^{38}$, which is attractive in comparison with monoculture as demonstrated in Table 3 (see Supplement for detailed discussion of studies).

Other than fungal mixed cultures, co-cultivation of yeast, bacteria and fungi have also been used to enhance the nutrient availability for animal feed under SSC, which will be discussed in section 3 of this perspective. 
Table 3 List of fungal co-cultures for producing other value-added products

\begin{tabular}{|c|c|c|c|c|}
\hline Product & Substrate & $\begin{array}{l}\text { Benefits or increased amount over } \\
\text { mono cultures }\end{array}$ & Co-culturing strains & References \\
\hline \multirow[t]{3}{*}{$\begin{array}{l}\text { Protein } \\
\text { enrichment for } \\
\text { animal feeds }\end{array}$} & Cassava lees & $\begin{array}{l}\text { Increase of protein from } 1.42 \% \text { to } 16.08 \% \\
\text { and } 18.54 \%\end{array}$ & $\begin{array}{l}\text { A. niger and Geotrichum sp } \\
\text { A. niger and Penicillium } \\
\text { sp.(ratio not specified) }\end{array}$ & 39 \\
\hline & Rapeseed meal & Decrease of glucosinolates by $90.71 \%$ & $\begin{array}{l}\text { A. oryzae and T. viride (ratio } \\
1: 1 \text { ) }\end{array}$ & 40 \\
\hline & $\begin{array}{l}\text { Sweet potato } \\
\text { residue }\end{array}$ & $10.2 \%$ to $24.1 \%$ increase in protein content & $\begin{array}{l}\text { Aspergillus sp. and Rhizopus } \\
\text { sp. (ratio } 1: 1)\end{array}$ & 41 \\
\hline Lovastatin & Red mold rice & $\begin{array}{l}\text { Up to } 64.7 \% \text { increment in lovastatin yield } \\
\text { over the mono culture of Monascus ruber } \\
\text { in literature } 42\end{array}$ & $\begin{array}{l}\text { Monascus purpureus and } \\
\text { Monascus ruber (ratio 1:1) }\end{array}$ & 43 \\
\hline $\begin{array}{l}\text { Decolorization } \\
\text { of textile dye }\end{array}$ & $\begin{array}{l}\text { Coomassie } \\
\text { brilliant blue, } \\
\text { bromophenol blue } \\
\text { and malachite } \\
\text { green }\end{array}$ & $-15.6 \%$ to $-21.8 \%$ degradation efficiency & $\begin{array}{l}\text { Trichoderma sp. and } A \text {. } \\
\text { flavus (ratio not specified) }\end{array}$ & 44 \\
\hline
\end{tabular}




\section{Bacterial co-cultures}

SSC has been used as a principal technology to produce biological pest control agents for crops, to prepare a fertilizer or to improve the quality and flavor of the product in traditional food fermentation in which bacterial co-cultures provided the biotransformation. The corresponding literature is listed in Table 4 (see Supplement for detailed discussion of studies). 
Table 4 List of bacterial co-cultures on SSC

\begin{tabular}{|c|c|c|c|c|}
\hline Product & Substrate & $\begin{array}{l}\text { Advantages or increased amount } \\
\text { over single culture }\end{array}$ & Co-culturing strains & References \\
\hline Biopesticide & Kitchen waste & $\begin{array}{l}\text { Decreased oil content thus facilitating } \\
\text { biopesticide production }\end{array}$ & $\begin{array}{l}\text { Bacillus thuringiensis and } \\
\text { Bacillus subtilis } \\
\text { (ratio } 3: 1-1: 3 \text { ) }\end{array}$ & 45 \\
\hline $\begin{array}{l}\text { Bioactive } \\
\text { compounds }\end{array}$ & Carrot pomace & $\begin{array}{l}\text { 10-fold increase in mucilage and } 6.2- \\
\text { fold increase in fibrinolytic enzyme } \\
\text { activity }\end{array}$ & $\begin{array}{l}\text { Bacillus subtilis and } \\
\text { Leuconostoc mesenteroides }\end{array}$ & 46 \\
\hline Vitamin $\mathrm{B}_{12}$ & $\begin{array}{l}\text { Agriculture crop } \\
\text { residues (sugar-cane } \\
\text { bagasse, wheat straw, } \\
\text { rice straw, bean straw } \\
\text { and cotton stalks) }\end{array}$ & $\begin{array}{l}\text { At least } 20 \% \text { increase in vitamin } B_{12} \\
\text { over mono cultures }\end{array}$ & $\begin{array}{l}\text { Bacillus firmus AZ-78B and } \\
\text { Streptomyces halstedii AZ- } 8 \mathrm{~A} \\
\text { (ratio 2:1) }\end{array}$ & 47 \\
\hline Fertilizer & $\begin{array}{l}\text { Corn stover, soybean } \\
\text { meal, bran }\end{array}$ & $\begin{array}{l}\text { Shortened fermentation period from } \\
72 \mathrm{~h} \text { to } 52 \mathrm{~h} \text { and increased spore } \\
\text { formation rate from } 50 \% \text { to } 90 \%\end{array}$ & $\begin{array}{l}\text { Bacillus mucilaginosus and } \\
\text { Bacillus megaterium (ratio 2:1) }\end{array}$ & 48 \\
\hline Lactic acid & Pine needles & $\begin{array}{l}\text { At least } 72 \% \text { increase in lactic acid } \\
\text { yield over mono Lactobacilli cultures }\end{array}$ & $\begin{array}{l}\text { Lactobacilli delbrueckii } \\
\text { (NCIM2025) and Lactobacilli } \\
\text { pentosus (NCIM 2912) (ratio not } \\
\text { specified) }\end{array}$ & 49 \\
\hline Vinegar & Grains and bran & Improved product flavor and quality & $\begin{array}{l}\text { Acetobacter rancens huniang } \\
1.01 \text {, Acetobacter pasteurianus } \\
\text { As } 1.41 \text {, two Gluconobaceter } \\
\text { isolates (ratio } 2: 1: 3: 2: 2 \text { ) }\end{array}$ & 50 \\
\hline
\end{tabular}




\section{Co-cultures of bacteria, yeast and fungi}

\subsection{Co-cultures for protein enrichment and animal feed production}

Microbial SSC conversion of agricultural byproducts or residues into cell protein has received much attention because it requires low level technology, increases protein availability in animal feed allowing direct use of the fermented product for feeding purposes as well as solving pollution and waste disposal problems. ${ }^{38,51}$ Co-culturing two or more strains are favored for protein enrichment because the synergism of the strains improves the digestibility and nutrient value of agriculture residues designed for animal feed products. Enterococcus faecium and Lactobacillus casei are important bacteria for the health of the lower gastrointestinal tract. They assist in $\mathrm{pH}$ modulation thereby creating an optimum environment for endogenous enzymes to process feed efficiently. A further benefit is that these bacteria produce bacteriocins that inhibit the proliferation of Escherichia, Salmonella and Clostridia. Bacillus subtilis are aerobes that produce a variety of enzymes with good protease, amylase, lipase, esterase and some xylanase and cellulase activity. The enzymes produced by the Bacillus strains also help to improve feed efficiency and conversion. Additions of fungi, such as Aspergillus and Rhizopus, increase the accessibility of the lignocelluloses or starch materials (Table 3). Yeasts, notably S. cerevisiae, are important probiotic organisms that help modulate the $\mathrm{pH}$ of the caecum and colon, as well as stimulate the growth of beneficial fiber and lactic acid-utilizing bacteria.

Processing parameters, such as moisture, $\mathrm{pH}$ of the substrate, inoculum size, temperature, and nitrogen source have been optimized to achieve the best synergistic effect from the mircoorganisms as illustrated in Table 5 (see Supplement for detailed discussion of studies).

Besides optimizing the process conditions for co-cultures to improve protein content, evaluation of the solid state fermented feed on animal performance is a frequent topic in the literature. Published reports have demonstrated the positive performances of SSC on nutrient digestibility by increasing the amount of water-soluble protein content as well as a reduction in pathogens by the accumulation of acetic acid. ${ }^{52,53}$ 
Table 5 List of co-cultures of bacteria, yeast and fungi for protein enrichment on SSC

\begin{tabular}{|c|c|c|c|}
\hline Substrate & $\begin{array}{l}\text { Protein yield/ enhancement in } \\
\text { comparisons with raw materials }\end{array}$ & Co-culturing strains & References \\
\hline $\begin{array}{l}\text { Rapeseed meal wheat bran, } \\
\text { corn flour and rice bran with } \\
\text { inorganic salts }\end{array}$ & $12.8 \%$ crude protein & $\begin{array}{l}\text { Geotrichum candidum and Bacillus } \\
\text { subtilus }\end{array}$ & 54 \\
\hline $\begin{array}{l}\text { Rapeseed meal, wheat bran } \\
\text { and brown sugar }\end{array}$ & $36.6 \%$ crude protein & $\begin{array}{l}\text { Lactobacillus fermentum, Enterococcus } \\
\text { faecium, } S . \text { cerevisae and Bacillus } \\
\text { subtilis (ratio } 1: 1: 1: 1 \text { ). }\end{array}$ & 53 \\
\hline Soybean meal, wheat bran & $\begin{array}{l}28.5 \% \text {, two-times higher than the } \\
\text { raw material }\end{array}$ & $\begin{array}{l}\text { A. niger, T. viride, S. cerevisiae, and } \\
\text { Candida utilis (ratio } 1: 1: 1: 3 \text { ) }\end{array}$ & 55 \\
\hline $\begin{array}{l}\text { Soybean meal, corn gluten } \\
\text { meal, rapeseed meal and } \\
\text { peanut meal }\end{array}$ & $\begin{array}{l}31 \% \text { with } 9.2 \% \text { of water soluble } \\
\text { protein }\end{array}$ & $\begin{array}{l}\text { Lactobacillus fermentum, S. cerevisae } \\
\text { and Bacillus subtilis (ratio } 1: 1: 1 \text { ) }\end{array}$ & 52 \\
\hline Sweet potato & $\begin{array}{l}\text { Increased by } 101 \% \text { in amino acid } \\
\text { composition over raw material }\end{array}$ & R. oligosporus and Candida arborea & 56 \\
\hline
\end{tabular}




\subsection{Co-cultures for ethanol or alcoholic drink}

Yeasts and bacteria co-cultures for ethanol fermentations, especially for co-fermenting glucose and xylose, have been widely investigated in submerged liquid cultivation ${ }^{57-59}$ while only a few reports on SSC co-cultures for ethanol have been published. Sree ${ }^{60}$ used a thermotolerant $S$. cerevisiae strain and a local isolate of an amylolytic Bacilllus sp. to produce fuel ethanol from sweet sorghum and sweet potato using SSC. More ethanol (42.3\% increase) was produced at 37 ${ }^{\circ} \mathrm{C}$ by the co-culture than by the thermotolerant yeast alone, due to the increased availability of reducing sugars from Bacillus sp.. A sequential co-culture of fungi and yeast was used to produce a traditional alcoholic drink from steamed cereals using SSC. ${ }^{61}$ The process involves two steps using fungus (generally, A. kawachii or A. oryzae) for saccharifying the feedstock and a yeast (usually, S. cerevisiae) for ethanol production. ${ }^{62}$ Seventy percent of total carbohydrates were converted to ethanol after 50 days of cultivation.

\section{Future aspects for solid substrate, liquid or submerged co-cultures}

\subsection{Considerations and techniques on establishment of co-culture system}

The criteria considered to select the co-culture systems include: 1) high compatibility between co-culture partners with little or no metabolic inhibitions; 2) compromise of the differentiation in culturing parameters to the mutual culture conditions; 3) maintaining the culture stability so no outcompeting occurs (except sequential co culture); 4) improved or even complete utilization of complex substrate cocktail; and 5) improved product yield and rate as compared to mono culture. These criteria characterize an efficient and feasible co-culture system, which assures process success. Further optimization of the co-culture (including optimal ratio of co-culture partners, moisture content, temperature, time, $\mathrm{pH}$, substrate, etc) will need to be deployed to improve the process efficiency with respect to product target, system stability and productivity. However, efficient screening and analytical techniques to predict the co-culture performance are not yet developed.

\subsubsection{Screening of co-culture system - Selectivity and compatibility}

When selecting microbial species for a co-culture system, the first step is to choose individual strains with the desired properties, then test their compatibility and study their co-fermentation 
performance. Screening technologies for identifying more desirable strains for co-culture systems are still under development. ${ }^{5}$ Usually the screening tests are performed on the petri dish to observe the organisms' compatibility or inhibitions, but this can only be regarded as prescreening due to the limited growth environment. Other requirements for a stable co-culture would still need to be verified, such as metabolic interactions (i.e., growth promoter or inhibitors) and mutually adjustable cultivation conditions. ${ }^{6}$ Candidates identified from prescreenings would need to be scaled up to eliminate uncertainty. Microbial growth rates, product tolerances, productivity and product yield of co-cultures also need to be quantified for selecting the optimum combination of microorganisms.

\subsubsection{Evaluation of the stability of co-cultures}

Culture stability is another trait vital to co-culture systems' success, yet one for which criteria have not yet been well established. Usually, the co-culture system is considered stable when the ratio of the live cells of the two organisms remains constant within the limits of experimental error, demonstrating that neither organism is outcompeting the other. The determination can be accomplished by the enumeration of the two microbial populations using the standard technique of a solid growth medium inoculated with serial dilutions of the broth cultures. However, this simple technique is only adapted to bacterial populations that can be differentiated on petri dish. Some researchers defined the criteria for structurally stable bacterial communities as one in which all the members persist over more than 20 times subculturing. ${ }^{6}$ But the adaptability of this criteria still needs to be explored and verified. ${ }^{6,63}$ Nowadays, analytical techniques from molecular biology like denaturing gradient gel electrophoresis (DGGE) are used to investigate the dynamics of microorganism populations and fermentation characteristics of in vitro cocultures. ${ }^{64}$

Additionally, besides screening for the optimum combination of co-culture, selection of cocultures which exhibit desired properties is another prospective method. Despite the advent of molecular biology and rational screening techniques, classical mutation still plays a major and irreplaceable role in improving industrial mono-cultures, and can also be an option for co-culture selection. To guarantee culture compatibility, cells or fungal spores can be blended together when exposed to the mutagenic agents instead of mutating the mono-culture separately. The 
difficulty of using classical mutation on a co-culture is in determining which micro-organism was significantly improved; i.e. separating the effects of the mutation(s) on the two different organisms.

\subsection{Solutions to determining the mechanism of the co-culture system}

A viable co-culture system will exhibit positive interactions between the two or more partners. However, the interactions between microorganisms in co-culture environments may not always correspond to desirable consequences. ${ }^{5}$ Therefore, knowing the interactions between associated strains in a co-culture system is essential. Very little research has been conducted in this area, mainly because of the difficulties involved in working with complex systems containing multiple microorganisms. Therefore, co-culture fermentations offer significant opportunities for future research.

\subsubsection{Current understanding on the co-cultural mechanism}

As evidenced by the cases illustrated above, the advantage of co-culture is evident in SSC because the slow growth of colonization allows better equilibration of populations and may degrade the substrate better in symbiotic associations as each species having its own niche for growth and substrate degradation. It is understandable that strains with different enzyme complexes can be combined to produce a suite of enzymes capable of achieving synergistic degradation of complicated substrates. But in the case of mutual products enhancement of the SSC co-culture, the underlying mechanisms have not been well elucidated in the literature, such as how the metabolism is reinforced on the proteomics and genetic level; how intense the cooperation and mutual interdependence is. One possible assumption is that one organism utilizes the metabolites (e.g. precursors of vitamins or certain amino acids) excreted from a partner organism and profits from this support even if it could synthesize the respective compound on its own. In this case, the microbes under such conditions may display more refined types of interaction with others. ${ }^{65}$ This kind of job-sharing among co cultures ascribes to every single organism only a limited task it has to fulfill and makes the whole process more efficient via saving biosynthetic energy. 


\subsubsection{Kinetic model}

In theory, a kinetic model can be used instead of experimentation to find optimum operating conditions which will maximize profitability, by accurately simulating the dynamic properties of the system. It is therefore usually believed to be advantageous to develop an appropriate kinetic model to characterize the desired co-culture systems. However, due to the difficulty in separating the kinetic parameters of each strain in a co-culture system, few modeling studies have been done to describe co-culture system dynamics. One possible solution to resolving the dynamic analysis of each strain is to use a molecular technique to observe population dynamics, such as DGGE, but this technique would increase experimental expense. Another solution is to regard the co- culture system as a mono culture, which ignores the details of the interactions between co-cultures thus avoiding the difficulty in differentiating each strain in the co-cultures. A logistic model has been used to closely predict product formation rate, and the authors state the model was successful by treating a co-culture system as mono culture. ${ }^{66}$

\subsubsection{Metabolic network model}

Another research tool which would allow better understanding of the mechanism of the coculture system is metabolic network modeling. A metabolic network model can be used for predicting metabolic pathways, explaining phenotypic behavior or designing ideal microbial strains for industrial production. ${ }^{67}$ To deal with the difficulty of discerning behavioral interactions between individual microbes, the manner in which products are exchanged between species can be inferred biochemically and genetically by developing a mutualism model for cocultured strains which have sequenced genomes. For a sequenced genome, a metabolic network model can be constructed from the biochemical and physiological information available. A combined metabolic model could be developed on the basis of the genome-scale reconstructed metabolic network model for each individual strain in a co-culture system, , which may illustrate the potential metabolic interactions between the two strains. ${ }^{5}$ Some publications have proven that reconstructed metabolic networks and stoichiometric models can also serve to capture growth parameters and community composition of simple bacterial communities besides predicting metabolic fluxes and growth phenotypes of single organisms. ${ }^{68,69}$

\subsection{Scale up of the co-culture fermentation process}




\subsubsection{Cultivation mode investigation in SSC}

The selection of fermentation configuration depends on the microbes used in the co-culture. Product yield improvement, inhibitor alleviation and efficient substrate utilization can be enhanced in liquid co-cultures by employing fed-batch or continuous modes. ${ }^{70}$ The related techniques which work in a mono culture or liquid co-cultures, such as feeding strategy, feedback/feedforward control and scale up modeling, can be extended to the SSC co-cultivations if well-verified yield performance, compatibility and stability have been determined. However, limited research is available focused on control of cultivation modes of the SSC co-culture systems due to lack of empirical data. Continuous flushing systems for SSC has been illustrated for cellulose conversion using Clostridium thermocellum by Dharmagadda et al. ${ }^{71}$. Chromatography columns fitted with porous polyethylene discs at the bottom were periodically flushed with culture medium and the solid substrate was retained. The flushed cultures exhibited higher cellulose conversion (25\%-47\%) than non-flushed SSC (<8\%). Other empirical approaches to designing the SSC process, like tray bioreactor (Koji-type processes) ${ }^{72}$ or deep bed bioreactors $^{73}$, and integrating these with downstream processing would be beneficial to support the investigation of the cultivation modes of SSC.

Another future research area will be to extend metabolic modeling to dynamic situations where SSC is performed in various cultivation modes, and the model can then assist with process control. The classical flux balance analysis method has been successfully extended for such dynamic situations in liquid cultures. ${ }^{74}$ Dynamic flux balance models can be gained by integrating stoichiometric equations for intracellular metabolism with dynamic mass balances on main substrates and products under the assumption of rapid intracellular changes. The cellular growth rate and substrate uptake kinetics provide the connection between the intracellular and extracellular models. This connection can be used to systematically interpret the regulatory effects such as inhibition by growth by-products. ${ }^{75}$

\subsubsection{Downstream processing}

Generally the design and cost of the downstream processing is dependent on process-related contaminates, including byproducts generated and remains of the host cells (proteins, nucleic acids) or the cell culture (components of the culture media used). Although in many cases, the 
performances of the co-cultures with respect to product yields are doubtless higher than single culture, the insufficient record of process-related inhibitors and contaminants which accumulate during cultivation overshadowed the influences on the product recovery in the downstream process or affected the entire process economics. Robust and cost-effective purification processes need to be developed or traditional processes modified in order to improve process efficiency and economics for co-cultures.

\subsection{Strategy of co-culture - an alternative to co-ferment the hydrolysates for biofuel production}

One of the bottlenecks in the field of lignocellulosic biofuels is the limited utilization of the sugars in the hydrolysates by the microorganisms, which significantly influences the fermentation efficiency and processing costs. The lack of industrially robust microbes for cofermentation of glucose and xylose has been a major technical barrier. Researchers have been trying to genetically modify microorganisms by creating pathways for xylose fermentation. Some genetically modified microorganisms have been engineered to ferment glucose and xylose for high ethanol yields (55-57 g/L), such as recombinant E. coli, Zymomonas mobilis ( $Z$. mobilis), and S. cerevisiae..$^{58,76,77}$ One remaining challenge is to control the sugar consumption rates so that one sugar does not end up being partially unconsumed even if the organism could consume the two or more sugars simultaneously.

Another approach is to co-culture microorganisms which vary in their sugar consumption for biofuel production. This appears to have advantages over single culture fermentations since coculturing provides an opportunity to adjust microbial populations to the changing sugar concentrations. Additionally, the co-culture can achieve simultaneous sugar conversion of C5 and C6 sugars, maximizing substrate utilization rate and increasing ethanol yield. Some research focus has been placed on the utilization of co-culture for ethanol production by co-fermenting glucose and xylose from various biomass hydrolysates. The yeast genus Saccharomyces or respiratory-deficient mutant is preferably used as the glucose-fermenting strain with a xylosefermenting strain such as Pichia stipitis used due to the compatible fermentation conditions of $\mathrm{pH}$, temperature and oxygen. Other co-cultures (E. coli, S. cerevisiae or Z. mobilis) were also shown to simultaneously consume xylose and glucose with either independent or overlapping pathways. ${ }^{59,78,79}$ 
However, due to the complexity and variety of the hydrolysates' composition (a function of the biomass itself and its corresponding hydrolysis methods), limited research has been conducted to improve the sugar utilization using co-cultures. For example, the sugars released from sugar beet pulp by enzymatic hydrolysis were mainly arabinose and glucose (15-18\%) instead of xylose and glucose. ${ }^{80}$ To develop robust co-culture systems for biomass conversion, a systematic study of the substrate-selective uptake range of each single strain needs to be explored. Understanding the strain compatibility and stability of the co-culture system will allow us to control and predict process performance. The metabolic pathways of each strain could then be further optimized for co-culturing to optimize yield and productivity of a particular product.

\section{Conclusion}

The examples of solid state co-culture processes in this perspective demonstrate the importance of this technique in the production of animal feed, enzymes, fertilizer and the process of bioremediation. Moreover, increasing demand for using renewable resources as feedstock for fermentative biofuel production, combined with advances in biotechnology and innovative process developments invokes further interest in solid state co-culture. Much of the interest is generated because SSC offers the opportunity to efficiently use inexpensive substrates by allowing microorganisms to act synergistically via a suite of enzymes specifically adapted for effectiveness in this solid niche. However, further progress in the co-culture technique will require a deep understanding of the interactions between associated strains in a co-culture system as well as developing efficient evaluation tools to monitor the co-culture's activity.

\section{Acknowledgments}

The authors gratefully acknowledge the financial support of the United States Department of Agriculture National Institute for Food and Agriculture Biomass Research and Development Initiative Grant \# 2011-10006-30363. The investigation reported in this paper (No. 13-05-042) is a part of a project of the Kentucky Agricultural Experiment Station and is published with the approval of the director. 


\section{References}

1. Pandey A, Soccol CR and Mitchell D, New developments in solid state fermentation: Ibioprocesses and products. Process Biochemistry 35: 1153-69 (2000).

2. Raghavarao K, Ranganathan TV and Karanth NG, Some engineering aspects of solid-state fermentation. Biochemical Engineering Journal 13: 127-35 (2003).

3. Chinn MS, Nokes SE and Strobel HJ, Screening of thermophilic anaerobic bacteria for solid substrate cultivation on lignocellulosic substrates. Biotechnology Progress 22: 53-59 (2006).

4. Peng $X$, Sun J, Iserentant $D$, Michiels $C$ and Verachtert $H$, Flocculation and coflocculation of bacteria by yeasts. Applied Microbiology and Biotechnology 55: 777-81 (2001).

5. Chen YL, Development and application of co-culture for ethanol production by cofermentation of glucose and xylose: A systematic review. Journal of Industrial Microbiology \& Biotechnology 38: 581-97 (2011).

6. Maki M, Leung KT and Qin WS, The prospects of cellulase-producing bacteria for the bioconversion of lignocellulosic biomass. International Journal of Biological Sciences 5: 500-16 (2009).

7. Sakai S, Imachi H, Sekiguchi Y, Ohashi A, Harada H and Kamagata Y, Isolation of key methanogens for global methane emission from rice paddy fields: A novel isolate affiliated with the clone cluster rice cluster i. Applied and Environmental Microbiology 73: 4326-31 (2007).

8. Stams AJM, Plugge CM, de Bok FAM, van Houten B, Lens P, Dijkman H and Weijma J, Metabolic interactions in methanogenic and sulfate-reducing bioreactors. Water Science and Technology 52: 13-20 (2005).

9. Raza F, Raza NA, Hameed U, Ikram ul H and Mariam I, Solid state fermentation for the production of b-glucosidase by co-culture of Aspergillus niger and $R$. oryzae. Pakistan Journal of Botany 43: 75-83 (2011).

10. Stoilova I and Krastanov A, Overproduction of laccase and pectinase by microbial associations in solid substrate fermentation. Applied Biochemistry and Biotechnology 149: 45-51 (2008).

11. Castillo MR, Gutierrezcorrea M, Linden JC and Tengerdy RP, Mixed culture solid substrate fermentation for cellulolytic enzyme-production. Biotechnology Letters 16: 967-72 (1994). 
12. Ahamed A and Vermette P, Enhanced enzyme production from mixed cultures of Trichoderma reesei rut-c30 and Aspergillus niger lma grown as fed batch in a stirred tank bioreactor. Biochemical Engineering Journal 42: 41-46 (2008).

13. Dashtban M, Schraft $\mathrm{H}$ and Qin WS, Fungal bioconversion of lignocellulosic residues; opportunities \& perspectives. International Journal of Biological Sciences 5: 578-95 (2009).

14. Maciel MJM, Silva ACE and Ribeiro HCT, Industrial and biotechnological applications of ligninolytic enzymes of the basidiomycota: A review. Electronic Journal of Biotechnology 13 (2010).

15. Holker $\mathrm{U}$, Hofer $\mathrm{M}$ and Lenz J, Biotechnological advantages of laboratory-scale solid-state fermentation with fungi. Applied Microbiology and Biotechnology 64: 175-86 (2004).

16. Brijwani K, Oberoi HS and Vadlani PV, Production of a cellulolytic enzyme system in mixed-culture solid-state fermentation of soybean hulls supplemented with wheat bran. Process Biochemistry 45: 120-28 (2010).

17. Jahangeer S, Khan N, Sohail M, Shahzad S, Ahmad A and Khan SA, Screening and characterization of fungal cellulases isolated from the native environmental source. Pakistan Journal of Botany 37: 739-48 (2005).

18. Juwaied AA, Al-amiery A and Anaam U, Optimization of cellulase production by Aspergillus niger and Tricoderma viride using sugar cane waste. Journal of Yeast and Fungal Research 2: 19-23 (2011).

19. GutierrezCorrea M and Tengerdy RP, Production of cellulase on sugar cane bagasse by fungal mixed culture solid substrate fermentation. Biotechnology Letters 19: 665-67 (1997).

20. Duenas R, Tengerdy RP and Gutierrezcorrea M, Cellulase production by mixed fungi in solid-substrate fermentation of bagasse. World Journal of Microbiology \& Biotechnology 11: 333-37 (1995).

21. Carvalheiro F, Roseiro JC and Collaco MTA, Biological conversion of tomato pomace by pure and mixed fungal cultures. Process Biochemistry 29: 601-05 (1994).

22. Dan S, Marton I, Dekel M, Bravdo BA, He SM, Withers SG and Shoseyov O, Cloning, expression, characterization, and nucleophile identification of family 3 , Aspergillus niger betaglucosidase. Journal of Biological Chemistry 275: 4973-80 (2000).

23. Wang $\mathrm{C}, \mathrm{Wu} \mathrm{G}$, Chen $\mathrm{C}$ and Chen $\mathrm{S}$, High production of $\beta$-glucosidase by Aspergillus niger on corncob. Applied Biochemistry and Biotechnology 168: 58-67 (2012).

24. Kumar R, Singh S and Singh OV, Bioconversion of lignocellulosic biomass: Biochemical and molecular perspectives. Journal of Industrial Microbiology \& Biotechnology 35: 377-91 (2008). 
25. Oberoi HS, Babbar N, Dhaliwal SS, Kaur S, Vadlani PV, Bhargav VK and Patil RT, Enhanced oil recovery by pre-treatment of mustard seeds using crude enzyme extract obtained from mixed-culture solid-state fermentation of kinnow (citrus reticulata) waste and wheat bran. Food and Bioprocess Technology 5: 759-67 (2012).

26. Dwivedi P, Vivekanand V, Pareek N, Sharma A and Singh RP, Bleach enhancement of mixed wood pulp by xylanase-laccase concoction derived through co-culture strategy. Applied Biochemistry and Biotechnology 160: 255-68 (2010).

27. Stoilova IS, Gargove SA and Krastanov A, Production of enzymes by mixed culture from micelial fungi in solid-state fermentation. Biotechnol\&Biotechnol 19: 103-08 (2005).

28. Gutierrez-Correa M and Tengerdy RP, Xylanase production by fungal mixed culture solid substrate fermentation on sugar cane bagasse. Biotechnology Letters 20: 45-47 (1998).

29. Juwaied AA, Adnan S and Al-amiery A, Production cellulase by different co-culture of Aspergillus niger and Tricoderma viride from waste paper. Journal of Yeast and Fungal Research 1: 108-11 (2010).

30. Wang XJ, Bai JG and Liang YX, Optimization of multienzyme production by two mixed strains in solid-state fermentation. Applied Microbiology and Biotechnology 73: 533-40 (2006).

31. Paranthaman R, Vidyalakshmi R, Murugesh S and Singaravadivel K, Effects of fungal coculture for the biosynthesis of tannase and gallic acid from grape wastes under solid state fermentation. Global Journal of Biotechnology \& Biochemistry 4: 29-36 (2009).

32. Jana A, Maity C, Halder SK, Mondal KC, Pati BR and Das Mohapatra PK, Tannase production by Penicillium purpurogenum paf6 in solid state fermentation of tannin-rich plant residues following ovat and rsm. Applied Biochemistry and Biotechnology 167: 1254-69 (2012).

33. Rodriguez-Duran LV, Contreras-Esquivel JC, Rodriguez R, Prado-Barragan LA and Aguilar $\mathrm{CN}$, Optimization of tannase production by Aspergillus niger in solid-state packed-bed bioreactor. Journal of Microbiology and Biotechnology 21: 960-67 (2011).

34. Paranthaman R, Vidyalakshimi R, Murgesh S and Singaravadivel K, Effects of fungal coculture for the biosynthesis of tannase and gallic acid from grape wastes under solid state fermentation. Global Journal of Biotechnology \& Biochemistry 4: 29-36 (2009).

35. Perinbam K, Kanimozhi S, Bharathy K and Ramnath V, Production of enzyme tannase by solid state fermentation using tamarind seed powder. Biosciences, Biotechnology Research Asia 6: 209-14 (2009).

36. Mukherjee $\mathrm{G}$ and Banerjee R, Effects of temperature, $\mathrm{pH}$ and additives on the activity of tannase produced by a co-culture of Rhizopus oryzae and Aspergillus foetidus. World Journal of Microbiology \& Biotechnology 22: 207-12 (2006). 
37. Banerjee R, Mukherjee $\mathrm{G}$ and Patra KC, Microbial transformation of tannin-rich substrate to gallic acid through co-culture method. Bioresource Technology 96: 949-53 (2005).

38. Yalemtesfa B, Alemu T and Santhanam A, Solid substrate fermentation and conversion of orange waste in to fungal biomass using Aspergillus niger ka-06 and Chaetomium spp kc-06. African Journal of Microbiology Research 4: 1275-81 (2010).

39. Ge R, Li H, Zhang H, Li b and Su Z, Screening of the strains for producing protein feeds by solid-state fermentation from cassava lees. Shengwu Jishu 20: 82-84 (2010).

40. Gu XH, Zhang YG, Zhao GM, Zhang R, Zhang F and Zhu JH, Improvement of feeding value of rapeseed meal by mix solid state fermentation Animal Husbandry and Feed Science 2: 12-17 (2010).

41. Yang SS, Protein enrichment of sweet-potato residue with coculture of amylolytic fungi by solid-state fermentation. Biotechnology Advances 11: 495-505 (1993).

42. Xu BJ, Wang QJ, Jia XQ and Sung CK, Enhanced lovastatin production by solid state fermentation of Monascus ruber. Biotechnology and Bioprocess Engineering 10: 78-84 (2005).

43. Panda BP, Javed S and Ali M, Optimization of fermentation parameters for higher lovastatin production in red mold rice through co-culture of Monascus purpureus and Monascus ruber. Food and Bioprocess Technology 3: 373-78 (2010).

44. Ramalingam, Saraswathy N, Shanmugapriya S, Shakthipriyadarshini S, Sadasivam S and Shanmugaprakash M, Decolorization of textile dyes by Aspergillus tamarii, mixed fungal culture and Penicillium purpurogenum. Journal of Scientific \& Industrial Research 69: 151-53 (2010).

45. Gong A, Qiu L, Wang D, Zhou L, Zhu Y, Zhang Z and Liu Q, Method for producing Bacillus thuringiensis (bt) biopesticide by co-culturing bt and Bacillus subtilis (bs) with kitchen waste via solid fermentation. China(2011).

46. Jung $\mathrm{H}$ and Lee $\mathrm{S}$, Production of carrot pomace fortified with mucilage, fibrinolytic enzyme and probiotics by solid-state fermentation using the mixed culture of Bacillus subtilis and Leuconostoc mesenteroides. Journal of Food Science and Nutrition 14: 335-42 (2009).

47. Atta H, Arafa R, Salem M and El-Meleigy M, Microbiological studies on the production of vitamin b12 from two mixed cultures under solid state fermentation condition. Journal of Applied Sciences Research 4: 1463-77 (2008).

48. Tian G, Zhang L and Li G, Method for preparing composite biological fertilizer by combined solid fermentation of double bacterium China patent CN 101585722 (2009).

49. Ghosh MK and Ghosh UK, Utilization of pine needles as bed material in solid state fermentation for production of lactic acid by lactobacillus strains. Bioresources 6: 1556-75 (2011). 
50. Song C, Zhang Q and Li L, Composite acetic acid bacteria, culture method thereof, and method for producing acetic acid through solid-state fermentation. China patent CN 101875908 (2009).

51. Pandey A, Selvakumar P, Soccol CR and Nigam P, Solid state fermentation for the production of industrial enzymes. Current Science 77: 149-62 (1999).

52. Hu JK, Lu WQ, Wang CL, Zhu RH and Qiao JY, Characteristics of solid-state fermented feed and its effects on performance and nutrient digestibility in growing-finishing pigs. AsianAustralasian Journal of Animal Sciences 21: 1635-41 (2008).

53. Chiang G, Lu WQ, Piao XS, Hu JK, Gong LM and Thacker PA, Effects of feeding solidstate fermented rapeseed meal on performance, nutrient digestibility, intestinal ecology and intestinal morphology of broiler chickens. Asian-Australasian Journal of Animal Sciences 23: 263-71 (2010).

54. Gu B, Ma H and Liu B, Preparation of bio-feedstuff with rich peptides from rapeseed meal by mixed solid fermentation. Journal of the Chinese Cereals and Oils Association 26 (2011).

55. Pan T, Zhang D, Zhao C and Li K, Study on microbial protein production by mixed culture solid-state fermentation on soybean waste. Fermentation and Bioindustrial Chemistry 16 (2004).

56. Wang P, Huang S and Yu B, Production of protein-enriched feed by direct bioconversion from sweet potato with mixed microbial culture. Food and Feed Chemistry 17 (2000).

57. Fu N, Peiris P, Markham J and Bavor J, A novel co-culture process with Zymomonas mobilis and pichia stipitis for efficient ethanol production on glucose/xylose mixtures. Enzyme and Microbial Technology 45: 210-17 (2009).

58. Eliasson A, Christensson C, Wahlbom CF and Hahn-Hagerdal B, Anaerobic xylose fermentation by recombinant Saccharomyces cerevisiae carrying xyl1, xyl2, and xks 1 in mineral medium chemostat cultures. Applied and Environmental Microbiology 66: 3381-86 (2000).

59. Okuda N, Ninomiya K, Katakura Y and Shioya S, Strategies for reducing supplemental medium cost in bioethanol production from waste house wood hydrolysate by ethanologenic Escherichia coli: Inoculum size increase and coculture with Saccharomyces cerevisiae. Journal of Bioscience and Bioengineering 105: 90-96 (2008).

60. Sree NK, Sridhar M, Rao LV and Pandey A, Ethanol production in solid substrate fermentation using thermotolerant yeast. Process Biochemistry 34: 115-19 (1999).

61. Fukuda H, Kizaki Y, Tsukihashi T and Wakabayashi S, Shochu brewing characteristics and properties of a trichothecin-resistant shochu yeast mutant. Biotechnology Letters 23: 2009-13 (2001). 
62. Murado MA, Pastrana L, Vazquez JA, Miron J and Gonzalez MP, Alcoholic chestnut fermentation in mixed culture. Compatibility criteria between Aspergillus oryzae and Saccharomyces cerevisiae strains. Bioresource Technology 99: 7255-63 (2008).

63. Kato S, Haruta S, Cui ZJ, Ishii M and Igarashi Y, Network relationships of bacteria in a stable mixed culture. Microbial Ecology 56: 403-11 (2008).

64. Sun YZ, Mao SY, Yao W and WY. Z, The dynamics of microorganism populations and fermentation characters of co-cultures of rumen fungi and cellulolytic bacteria on different substrates. Wei Sheng Wи Хие Bao 46: 422-26 (2006).

65. Schink B, Syntrophic associations in methanogenic degradation. Progress in Molecular and Subcellular Biology 41: 1-19 (2006).

66. Manikandan $\mathrm{K}$ and Viruthagiri $\mathrm{T}$, Optimization of $\mathrm{C} / \mathrm{N}$ ratio of the medium and fermentation conditions tapioca starch using co - culture of Aspergillus niger. International Journal of ChemTech Research 2: 947-55 (2010).

67. Cho BK, Charusanti P, Herrgard MJ and Palsson BO, Microbial regulatory and metabolic networks. Current Opinion in Biotechnology 18: 360-64 (2007).

68. Stolyar S, Van Dien S, Hillesland KL, Pinel N, Lie TJ, Leigh JA and Stahl DA, Metabolic modeling of a mutualistic microbial community. Molecular Systems Biology 3 (2007).

69. Pramanik J and Keasling JD, Stoichiometric model of Escherichia coli metabolism: Incorporation of growth-rate dependent biomass composition and mechanistic energy requirements. Biotechnology and Bioengineering 56: 398-421 (1997).

70. Laplace JM, Delgenes JP, Moletta R and Navarro JM, Cofermentation of glucose and xylose to ethanol by a respiratory-deficient mutant of Saccharomyces cerevisiae co-cultivated with a xylose-fermenting yeast. Journal of Fermentation and Bioengineering 75: 207-12 (1993).

71. Dharmagadda VSS, Nokes SE, Strobel HJ and Flythe MD, Investigation of the metabolic inhibition observed in solid-substrate cultivation of Clostridium thermocellum on cellulose. Bioresource Technology 101: 6039-44 (2010).

72. Durand A, Bioreactor designs for solid state fermentation. Biochemical Engineering Journal 13: $113-25$ (2003).

73. Brijwani K, Vadlani PV, Hohn KL and Maier DE, Experimental and theoretical analysis of a novel deep-bed solid-state bioreactor for cellulolytic enzymes production. Biochemical Engineering Journal 58-59: 110-23 (2011).

74. Mahadevan R, Edwards JS and Doyle FJ, Dynamic flux balance analysis of diauxic growth in Escherichia coli. Biophysical Journal 83: 1331-40 (2002). 
75. Lisha KP and Debasis S (2011) Dynamic flux balance modeling of fed-batch co-culture fermentation of glucose/xylose mixture for improved bioethanol in 3rd International Conference on Chemical, Biological and Environmental Engineering, LACSIT Press, Singapore.

76. Qureshi N, Dien BS, Nichols NN, Saha BC and Cotta MA, Genetically engineered Escherichia coli for ethanol production from xylose - substrate and product inhibition and kinetic parameters. Food and Bioproducts Processing 84: 114-22 (2006).

77. Zhang M, Eddy C, Deanda K, Finkestein M and Picataggio S, Metabolic engineering of a pentose metabolism pathway in ethanologenic Zymomonas mobilis. Science 267: 240-43 (1995).

78. Eiteman M, Lee $\mathrm{S}$ and Altman E, A co-fermentation strategy to consume sugar mixtures effectively. Journal of Biological Engineering 2: 1-8 (2008).

79. Patle $\mathrm{S}$ and Lal B, Ethanol production from hydrolysed agricultural wastes using mixed culture of Zymomonas mobilis and Candida tropicalis. Biotechnology Letters 29: 1839-43 (2007).

80. Rorick R, Nahar N and Pryor S (2009) Enzymatic hydrolysis and fermentation of sugar beet pulp in American Society of Agriculture and Biological Engineering Nevada.

81. Duff SJB, Cooper DG and Fuller OM, Cellulase and beta-glucosidase production by mixed culture of Trichoderma reesei rut c30 and Aspergillus phoenicis. Biotechnology Letters 7: 18590 (1985).

82. Mukherjee $\mathrm{G}$ and Banerjee $\mathrm{R}$, Biosynthesis of tannase and gallic acid from tannin rich substrates by Rhizopus oryzae and Aspergillus foetidus. Journal of Basic Microbiology 44: 42-48 (2004).

83. Nigam P, Process selection for protein-enrichment - fermentation of the sugar-industry byproducts molasses and sugar-beet pulp. Process Biochemistry 29: 337-42 (1994).

84. Demain AL, Pharmaceutically active secondary metabolites of microorganisms. Applied Microbiology and Biotechnology 52: 455-63 (1999).

85. Manzoni M and Rollini N, Biosynthesis and biotechnological production of statins by filamentous fungi and application of these cholesterol-lowering drugs. Applied Microbiology and Biotechnology 58: 555-64 (2002).

86. Chang YN, Huang JC, Lee CC, Shih IL and Tzeng YM, Use of response surface methodology to optimize culture medium for production of lovastatin by Monascus ruber. Enzyme and Microbial Technology 30: 889-94 (2002).

87. Chang YN, Lin YC, Lee CC, Liu BL and Tzeng YM, Effect of rice-glycerol complex medium on the production of lovastatin by Monascus ruber. Folia Microbiologica 47: 677-84 (2002). 


\section{Supplement}

\section{Discussion of the studies in Table 1}

\section{$\underline{\text { Co cultures for cellulase system }}$}

Various mixed cultures of Aspergillus species were tested by Raza. ${ }^{9}$ Among each of the two genera combinations of A. niger, A. awamori and A. oryzae, the co- culture of A. niger and A. oryzae at a ratio of $3: 1$ gave the highest production rate of $\beta$-glucosidase, $2975 \pm 5.3 \mathrm{U} / \mathrm{g} / \mathrm{min}$ at $\mathrm{pH} 5.0$ among all the tested combinations, which was more than ten-fold higher productivity than similar monocultures.

Brijwani et al. ${ }^{16}$ demonstrated that co-culturing of $T$. reesei with A. oryzae in 1:1 ratio boosted the production of $\beta$-glucosidase activity by $65 \%$ in SSC of soybean hulls supplemented with wheat bran, when compared to a monoculture of $T$. reesei. The co-culture system also synergistically produced $100 \mathrm{IU} / \mathrm{g}$ endocellulase while only $60 \mathrm{IU} / \mathrm{g}$ and $68 \mathrm{IU} / \mathrm{g}$ were obtained with a monoculture of $T$. reese $i$ and A. oryzae, respectively. A mixed culture of $T$. reesei and $A$. phoenicis in SSC using bagasse was investigated by Duenas et al. ${ }^{20}$ to produce a cellulase with an increased activity of $\beta$-glucosidase (See Table 1 ). The highest cellulase and $\beta$-glucosidase by co-culture obtained were 18.7 and $38.6 \mathrm{IU} / \mathrm{g}$, respectively, representing approximately 3 - and 6fold increase over the activities attained in single-culture SSC. The same co-culture system was adopted by Gutierrez-Correa and Tengerdy ${ }^{19}$ and up to 2.7-, 3.8- and 2.3-fold increase of activities of cellulase, endoglucanase and $\beta$-glucosidase respectively over that from monocultures. In addition, the reported volumetric productivity rates of cellulase production using co-culture SSC by Duenas et al. ${ }^{20}$ and Gutierrez-Correa and Tengerdy ${ }^{19}$ were $280 \mathrm{IU} . \mathrm{L}^{-1} \cdot \mathrm{h}^{-}$ ${ }^{1}$ and $210 \mathrm{IU} \cdot \mathrm{L}^{-1} \cdot \mathrm{h}^{-1}$ with no washed dilution, respectively, significantly higher than that obtained in mixed submerged fermentations; $12.5 \mathrm{IU} \cdot \mathrm{L}^{-1} \cdot \mathrm{h}^{-1}$ by T. reesei and A. phoenicis ${ }^{81}$, which demonstrated an advantage of SSC over SmF in terms of concentrated activities. Juwaied ${ }^{29}$ tested co-cultures of A. niger and T. viride at various coculture initiation times. The study found 
that the cellulase obtained from the continuously mixed cultures had maximum activity (about $2.4 \mathrm{U} / \mathrm{ml}$ ) as compared to their pure cultures (about 0.6-1.0 U/ml).

Co cultures for multiple enzyme complexes

T. reesei was co-cultured with either A. niger or A. phoenicis in SSC on sugar cane bagasse and this resulted in higher xylanase activities than their corresponding monocultures. When soymeal was used as the nitrogen supplement at a C:N ratio of 10:1, activity levels of xylanase $(2,600-$ $2,800 \mathrm{IU} / \mathrm{g}$ dry biomass) and cellulase (14 - $15 \mathrm{IU} / \mathrm{g}$ dry biomass), corresponding to 35 - $45 \%$ and 20 - 142\% higher than single cultures of either partner, were obtained by both mixed-culture systems after 72 hours of fermentation. ${ }^{28}$ Another study produced both xylanase and laccase by mutant Penicillium oxalicum SAUE-3.510 cultured with Pleurotus ostreatus MTCC 1804 under SSC and the collected enzyme mixture (xylanase/laccase, 22:1) of $8 \mathrm{IU} / \mathrm{g}$ bleached the mixed wood pulp with a notable decrease of $21 \%$ in kappa number and increase of $8 \%$ in brightness as compared to xylanase alone. ${ }^{26} \mathrm{Wang}^{30}$ selected the co-culture of two strains of A. niger (in a proportion of 1:4) and optimized the medium with $54.5 \%$ (w/w dry basis) water and demonstrated that the activities of cellulase, hemicellulase, glucoamylase, pectinase, and acidic protease acted together to provide a $65 \%$ increase in reducing sugars released as compared to each monoulture. Stoilova ${ }^{27}$ cultivated Thermoascus aurantiacus with A. niger strains A and B respectively in SSC. A synergistic effect was observed between Thermoascus aurantiacus and A. niger $-A$. Higher activity of $\beta$-glucosidase $(500 \mathrm{IU} / \mathrm{g}$ ) was produced, surpassing the activity from the monoculture of A. niger - A by a factor of 2.5. The synergism between the species Thermoascus aurantiacus and A. niger - B led to an increased biosynthesis of laccase (31IU/g) and glucoamylase (308 IU/g), which was an activity 1.5 times higher than that of the $T$. aurantiacus monoculture. Two microbial fungal associations, A. niger \& Fusarium moniliforme and Trametes versicolor \& A. niger, were investigated in a study by Stoilova and Krastanov. ${ }^{10}$ The synergism between A. niger and Fusarium moniliforme increased the biosynthesis of $\alpha$ amylase and pectinase, necessary for fungal growth. Trametes versicolor and A. niger proved to be compatible partners to produce high activity of laccase (97,600 IU/g dry weight substrate), surpassing the enzymatic activity level in the monoculture by a factor of 8.4 .

\section{Discussion of the studies in Table 2}


Co-culture of $R$. oryzae and $A$. foetidus is one of the most widely investigated microbial combinations for bio-converting tannin-rich substrate to gallic acid. When either strain, $R$. oryzae or A. foetidus was grown separately under SSC on powdered fruits of Terminalia chebula and Caesalpinia digyna pod, A. foetidus showed a marginally higher yield of tannase activity (36.4 $\mathrm{U} / \mathrm{ml}$ in $72 \mathrm{~h})$ than $R$. oryzae $(31.8 \mathrm{U} / \mathrm{ml}$ in $60 \mathrm{~h})$, however $A$. foetidus required a longer incubation period to produce this amount of enzyme activity. ${ }^{82}$ A higher amount of tannase (41.3 $\mathrm{U} / \mathrm{ml}$ ) was produced in a shorter time period ( $48 \mathrm{~h}$ ) by these two fungal strains together than monoculture under SSC using the same substrate. ${ }^{37}$ Mukherjee $^{36}$ investigated the effects of temperature and $\mathrm{pH}$ on the activity of purified tannase produced by co-culturing $R$. oryzae and A. foetidus on the fruits of Terminalia chebula and teri pod with the culture conditions of $40{ }^{\circ} \mathrm{C}$ and 5.0 respectively.

Other fungal combinations for tannase production were investigated successfully. Among the co-cultures of : A. niger and P. chrysogenum; P. chrysogenum and T. viride; A. niger and T. viride; A. niger \& P. chrysogenum \& T. viride using grape's peel as a substrate, the optimal combination was $P$. chrysogenum and $T$. viride which produced enzyme activity of $84 \pm 2$ $\mathrm{U} / \mathrm{g} / \mathrm{min}$, which was higher than the respective mono cultures $(61-63 \mathrm{U} / \mathrm{g} / \mathrm{min}) .{ }^{34}$

\section{Discussion of the studies in Table 3}

Mixed fungal cultures generate diverse enzymes permitting transformation of raw materials or agricultural residues into high protein biomass with interesting amino acid compositions. Combinations of amylolytic Aspergillus sp. and Rhizopus sp. on sweet potato residue showed higher protein enrichment (32.4\% protein) than mono cultures of fungus (26\% $-29 \%$ protein) and amylolytic yeast (17-18.4\% protein). ${ }^{41}$ For agricultural residues and lignocellulose materials containing fiber and other anti-nutrients, high levels of enzymatic production during SSC, especially of cellulolytic enzymes, enhanced the digestibility of the materials designed for animal feed products and furthered the interest in SSC of mixed cultures. ${ }^{10,83}$ Co-cultures like Aspergillus sp. and T. viride using rapeseed meal or Aspergillus sp. and Penicillium sp. using food waste like cassava lees (byproduct in the process of alcohol production by utilizing cassava) demonstrated the ability to use fiber (decreased by 19-22\%) thus stimulating the accumulation of nitrogenous nutrients. ${ }^{39,40}$ 
As discussed above, co-culture of fungi on SSC helps in maximizing the utilization of substrate; moreover co-cultures provide support for secondary metabolite production. A typical example is fermented rice (red mold rice) by mold, which has been applied as a functional food to reduce the serum total cholesterol and triglycerides due to presence of lovastatin in the fermented rice. ${ }^{84}$, ${ }^{85}$ Different Monascus species such as M. ruber, M. purpureus, M. anka, and M. pilosus are utilized in China to produce red mold rice. Co-cultures of M. purpureus MTCC 369 and $M$. ruber MTCC 1880 under SSC were reported to yield $2.83 \mathrm{mg} / \mathrm{g}$ lovastatin in red mold rice under optimized process conditions. ${ }^{43} \mathrm{Up}$ to $64.7 \%$ increment in lovastatin yield over the mono culture of M.ruber reported by $\mathrm{Xu}^{42}$. By volume, this yield is equivalent to about $1.4 \mathrm{~g} / \mathrm{L}$ losvatin, which represents about 8.8 10.5-fold increase over the yield of lovastatin generated by mono culture under optimized submerged liquid conditions in other papers. ${ }^{86,87}$

Not all fungal co-cultures demonstrated better performances than monoculture however. The degradative ability of $A$. tamari, $P$. purpurogenum and mixed culture (Trichoderma sp., and A. flavus) on various synthetic dyes were described by Ramalingam. ${ }^{44}$ The results showed that each monoculture completely decolorized coomassie brilliant blue after 20 days while mixed cultures decolorized coomassie brilliant blue, bromophenol blue and malachite green with a $15.6 \%$ $21.8 \%$ decrease in degradation efficiency. The intrinsic reasons were not investigated in the study. In addition, lack of comparison with the monoculture of Trichoderma sp. and A. flavus in this study did not allow differentiation between monoculture effects and synergistic effects of the co-culture.

\section{Discussion of the studies in Table 4}

Solid substrate bacterial co cultures have been reported to produce biological pest control agents or produce a fertilizer. Gong ${ }^{45}$ inoculated 10-30\% (by mass) Bacillus thuringiensis and Bacillus subtilis into kitchen waste containing 45-60\% water for pesticide production. The main advantage of using the probiotic Bacillus subtilis lies in its ability to effectively degrade oils in kitchen waste. Atta ${ }^{47}$ selected two microbial isolates for their high yield of vitamin $\mathrm{B}_{12}$; $\mathrm{a}$ bacteria (Bacillus firmus AZ-78B) and an actinomycete (Streptomyces halstedii, AZ- 8A) from among 140 microbial isolates from soil. The co-culture of these two microorganisms produced $37.7 \mu \mathrm{g} / \mathrm{ml}$ of vitamin $\mathrm{B}_{12}$ from agricultural crop residues which translates to more than a $20 \%$ 
increase over mono-cultures. Tian ${ }^{48}$ used Bacillus mucilaginosus and Bacillus megaterium to produce an efficient composite bacterial fertilizer by adjusting the ratio of inoculum to 2:1 and controlling the cultivation conditions at various stages of production. The process improved with the co-culture by demonstrating an accelerated strain propagation, short fermentation period of $52 \mathrm{~h}$ (traditionally $72-100 \mathrm{~h}$ ) and high spore formation rate of 90\% (50-70\% for mono-cultures) thus significantly lowering the production cost. In other applications, Bacillus subtilis HA and Leuconostoc mesenteroides were co-cultivated on carrot pomace by SSC to increase production of the bioactive compounds, such as $24 \%$ (g/g) of mucilage content (2.31\% by Bacillus subtilis alone), fibrinolytic enzyme of $104.9 \mathrm{U} / \mathrm{g}$ (16.95 U/g by Bacillus subtilis) and probiotics. The fermented carrot pomace could be utilized as a valuable ingredient for functional foods or in the cosmetic industries. ${ }^{46}$

Another interesting prospect is that co-cultivation of bacteria may be an effective method to overcome the recalcitrance of biomass. Ghosh ${ }^{49}$ utilized pine needles as feedstock in lactic acid production in SSC using L. delbrueckii (NCIM2025) and L. pentosus (NCIM 2912). They saw a greater than $72 \%$ increase in the yield of lactic acid over mono cultures ( 8.72 to $26.15 \mathrm{~g} / \mathrm{L}$ ).

In traditional food fermentation, co-cultures of bacteria played a vital role in improving the quality and flavor of the final product. Song ${ }^{50}$ screened five types of composite acetic acid bacteria from fermented grains of Shanxi mature vinegar. The composite acetic acid bacteria culture solution was inoculated into fermented grains and bran using SSC. The mixed culture improved acetic acid production rate, shortened fermentation time, and increased gluconic acid content in the suite of metabolites. The quality of the obtained table vinegar was also improved.

\section{Discussion of the studies in Table 5}

Research on co-cultures of bacteria, yeast and fungi for protein enrichment and animal feed mainly involves identification of suitable process parameters. $\mathrm{Gu}^{54}$ reported that the combination of Geotrichum candidum and Bacillus subtilis resulted in the highest protein enrichment $(12.81 \%)$ among the other combinations of A. oryzae, Geotrichum candidum, Candida tropicalis, Saccharomyces cerevisiae (S. cerevisiae) and Bacillus subtilis grown on rapeseed meal and salts $\left(\mathrm{CaCl}_{2} 0.1 \%\right.$ and $\left.\mathrm{NH}_{4} \mathrm{Cl} 1.5 \%\right)$. The study by Chiang ${ }^{53}$ showed protein enrichment of up to 
$36.6 \%$ by a mixed culture of Lactobacillus fermentum, Enterococcus faecium, Saccharomyces cerevisae and Bacillus subtilis (30-day culture) on rapeseed meal supplemented with wheat bran and brown sugar. Pan ${ }^{55}$ enriched crude protein from soybean meal by optimizing cultivation conditions which were as follows: inoculum volume A. niger: T. viride: S. cerevisiae: Candida utilis $=1: 1: 1: 3$, initial $\mathrm{pH}$ value of 5.5 and cultivation temperature of $32{ }^{\circ} \mathrm{C}$. Under the optimum conditions, the amount of crude protein could be as high as $28.5 \%$ on a dry basis, which was approximately twice that of the raw material. $\mathrm{Hu}^{52}$ designed a substrate medium containing soybean meal, corn gluten meal, rapeseed meal and peanut meal for co-culturing Lactobacillus fermentum, S. cerevisae and Bacillus subtilis. The crude protein increased to $31 \%$ with $9.2 \%$ of water soluble protein after a 30-day culture. A mixed culture of $R$. oligosporus and Candida arborea using SSC in a shallow dish (length $\times$ width $\times$ height $=290 \mathrm{~mm} \times 190 \mathrm{~mm} \times 55 \mathrm{~mm}$ ) enriched protein from sweet potato to $22.1 \%$ when fermented at $28^{\circ} \mathrm{C}$ for $72 \mathrm{~h}$. Using a solidsubstrate bioreactor (length $\times$ width $\times$ height $=500 \mathrm{~mm} \times 350 \mathrm{~mm} \times 250 \mathrm{~mm}$ ) for $48 \mathrm{~h}$ at $28^{\circ} \mathrm{C}$, $15.9 \%$ crude protein was obtained. The total amount of amino acids were increased by $101 \%$, compared with that of raw material. ${ }^{56}$ 